ACTA VET. BRNO, 55, 1986:319-332

\title{
LUTEOLYTICS IN THE PROCESS OF CONTROLLED REPRODUCTION OF HEIFERS IN RELATION TO PREGNANCY AND SYNCHRONISED CALVING
}

\author{
A. JIŘTČEK and L. HOL $\dot{Y}$
}

Slušovice Agricultural Cooperative and Department of Farm Animal Reproduction and Surgery, University of Veterinary Science, 61242 Brno

Received July 27, 1985

A b s t r a c t

J i r I č e K A., Holý L . : Luteolytics in the Process of Controlled Reproduction of Heifers in Relation to Pregnancy and Synchronised Calving. Acta vet. Brno, 55, 1986: 319-332.

On the basis of a single clinical selection of animals, in order to synchronise oestrus according to the presence of a corpus luteum in the ovary, a single dose of Cloprostenol-based luteolytics (Estrumate from ICI and Oestrophan.from Spofa) at $500 \mu g \mathrm{i}$. m. was administered to a total of 3834 heifers of various breeds.

The first group consisted of 428 heifers, of which 402 (98\%) were inseminated and 298 , i. e. $74.12 \%$, became pregnant in the postsynchronisation oestrus. Following a further two inseminations in all 98\% of the heifers conceived, with an insemination index of 1.24 .

Out of 202 control animals inseminated in the traditional manner, $54 \%$ became pregnant after the first insemination and a total of $94.05 \%$ of animals conceived, with an insemination index of 1.63 .

The whole experimental group of synchronised heifers which became pregnant in the Ist, IInd and IIIrd postsynchronisation oestrus conceived on average 7.37 days after the initial synchronisation insemination, which accelerated their entry into reproduction by 24.8 days compared to their conventionally inseminated counterparts.

It was confirmed that clinical selection of animals for synchronisation on the basis of the presence of a corpus luteum in the ovary is highly effective and depends on the accuracy of the diagnosis of the presence of a corpus luteum.

In the second experimental group, using similar criteria for selection, 3406 heifers were synchronised, of which 2465 animals conceived in the postsynchronisation oestrus, i. e. an average of $72.2 \%$.

In the third group a study was made of the onset of calving following synchronised insemination in 303 pregnant heifers of Friesian and Bohemian Pied cattle. Calving took place from the 262 nd to the 290 th day of gestation at an interval of 29 
days, with maximum frequency between the $273 \mathrm{rd}$ and the $290 \mathrm{th}$ days, when 70.62 of all heifers calved. Synchronisation, prostaglandin $F_{2 a l p h a}$, corpus luteum, conception, calving,
luteolysis.

Controlled reproduction, an essential part of the intensification of cow and heifer production, means the active intervention of man in the reproduction process of animals in that he makes the most of their natural reproduction potential to optimise natality, which is a prerequisite of selection and improvement of the qualities of our herds.

An important role in the current managoment of reproduction is played by the artificial regulation of the sexual functions of animals using luteolytics, which are capable of synchronising the sexual activity of large groups of production animals and thus creating the conditions required for the synchronised regulation of the reproduction cycle both at its start (insemination) and its climax (calving).

Endogenous luteolytics represented by $P G F$ fol ( $H$ a $s$ et al.

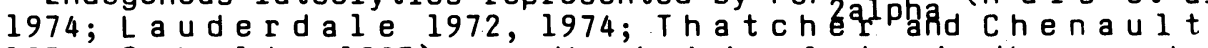
1976; Schultz 1983), are the decisive factor in the repeatability of the sexual cycle in that in the presence of follicular or oestrogen components in the ovary they induce regression of the corpus luteum. The destruction of the follicular apparatus on the 9 th to the listh day of the cycle leads to the long-term survival of the corpus luteum, which maintains a weight of around $5.5 \mathrm{~g}$ for another 24 days, which is incomparable with controls, where the weight of the corpus luteum is around $1.1 \mathrm{~g}$ ( $T$ hatcher et al. 1985).

In the presence of a follicular population in the ovary the regression of the corpus luteum is also brought about by the exogenous administration of a luteolytic ( $L$ o u i s et al. 1975; Thatcher et al. 1985), and this fact has for many years been exploited in broad practical applications both for synchronisation of oestrus ( $L$ a uderdale 1972, 1974; Rowson et al. 1972; Cooper 1974; We lch et al. 1975; Haf s et al. 1975; Schultz 1976; Fulka et al. 1976; Kudlác et al. 1976, 1977; B a $1 \mathrm{l}$ et al. 1980; $\mathrm{Humbol}$ and $\mathrm{Th}$ i bie r 1980;

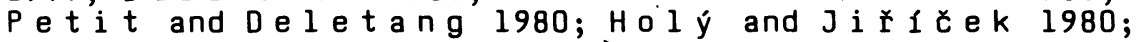
$\mathrm{Kudl}$ ác and $\mathrm{HOl} \dot{y}$ 1984, etc.), and for therapeutic purposes (R Ob 1983; S e v č $1 \mathrm{k}$ and $R$ e iche l 1983; Ji r a n et al. 1983; Reichel and Sevé Iková 1984, atc.).

The subject of this work is an evaluation of the luteolytic or synchronisation effect of analogues of Prostaglandin F2alpha - Cloprostenol, in the form of the specialities Estrumate (ICI) and Destrophan (Spofa) in relation to the onset of oestrus, the pregnancy rate and the resultant frequency of calving in large concentrations of animals at the Slusovice Agricultural Cooperative, and is based on preliminary studies carried out in 1980 and 1982 ( Holý and Jícek 1980; G a r gulak 1982). 


\section{Materials and Methods}

The luteolytic and synchronisation effect of Cloprostenol at a dose of $500 \mathrm{~kg} \mathrm{i.} \mathrm{m.} \mathrm{(Estrumate,} \mathrm{ICI)} \mathrm{was} \mathrm{investigated} \mathrm{systema-}$ tically from 1978, so that by the end of 1984 we had included a total of 4009 experimental and control animals in the experiments. Some of the experimental material belonged to the Friesian black and white cattle breed, some to the Bohemian Pied cattle breed and other animals were the result of crossings detween these two, possibly also other breeds.

Heifers were introduced into the experiments when they passed from pasture herds to main herds, in accordance with the needs of the cooperative.

In the first phase of the experiments (experiment no. 1), which took place between February 2 and September 13, 1978, we made a detailed check on both the selection of heifers and the postsynchronisation course of their sexual activity, and evaluated not only the onset and the quality of oestrus, but also the level of conception, or the economic advantages of synchronisation in relation to a control group which was introduced into the reproduction process by conventional means within the framework of the normal insemination programme.

The synchronisation of heifers was carried out at a mean age of 14 - 18 months, a weight of 330 - $350 \mathrm{~kg}$, and with a daily increment following conception of ca. $0.7 \mathrm{~kg}$. For synchronisation the heifers were taken from pasture herds and placed in tied sheds. Before treatment all animals were subjected to a single selective clinical examination of the condition and function of the reproductive organs and their suitability for synchronisation was assessed according to the presence of a clear corpus luteum in the ovary. This eliminated from the synchronisation process animals with anomalies of the reproductive organs and heifers not yet fully sexually mature. Animals in oestrus which were not susceptible to luteolytic treatment were either moved into the next round of synchronisation or inseminated by conventional means. Initial clinical selection was also carried out in the case of the control animals, where the detection of oestrus and insemination were performed by conventional methods from the day the luteolytics were administered to the experimental group.

Animals selected for synchronisation on the basis of the presence of a corpus luteum in the ovary were given a single dose of $500 \mathrm{ug}$ Cloprostenol (Estrumate) $\mathrm{i} . \mathrm{m}$. and the heifers were placed in a single shed in order to simplify their monitoring. The first insemination of animals in oestrus was undertaken $72 \mathrm{~h}$ after the administration of the luteolytic, the second 18 - $20 \mathrm{~h}$ later, but only where signs of oestrus persisted. Insemination was always performed by the same worker and semen from the same bull was used for each insemination or synchronisation round.

The effect of luteolysis was assessed according to the onset of signs of oestrus and the results of conception after synchronised insemination were ascertained by rectal examination after 42 - 56 days following insemination.

A similar method of clinical selection and means of synchronisation were used in the case of the second group of animals 
(group 2), which was synchronised mainly with Destrophan (Spofa), according to the commercial interests of the cooperative, and the administration of luteolytics was also conditioned by the presence of a corpus luteum in the ovary. The experiments were carried out in 1982,1983 and 1984 .

In heifers which were left in the Slušovice AC herd (group 3 ), we also evaluated the length of gestation, particularly in effect of synchronised insemination on the possible synchronisation of calving.

Results and Discussion

The results of luteolytic treatment and insemination of heifers (group 1) synchronised from February 2 to September 13, 1978 are shown in Tab. 1. The table also gives a comparison of the effectiveness of synchronisation from the viewpoint of the entry of experimental and control animals into the reproduction process, limited by conception.

Table 1

Group comparison of individual indicators of fertility in heifers synchronised with luteolytics (Cloprostenol $500 \mathrm{\mu g}$ i.m. and control animals of various breeds (Estrumate)

\begin{tabular}{|c|c|c|c|c|c|c|c|}
\hline $\begin{array}{l}\text { Group } \\
\text { of } \\
\text { animals }\end{array}$ & $\begin{array}{l}\text { Number } \\
\text { of } \\
\text { heifers }\end{array}$ & $\begin{array}{l}\text { Co n c e } \\
\text { Synchro- } \\
\text { nized } \\
\text { No. } \% \\
\text { of \% } \\
\text { anim. }\end{array}$ & $\begin{array}{l}\text { p t i o n } \\
\text { After IInd } \\
\text { insem. } \\
\text { No. } \\
\text { of } \% \\
\text { anim. }\end{array}$ & $\begin{array}{l}\text { i n } \% \\
\text { Total } \\
\text { No. } \\
\text { of } \\
\text { anim. }\end{array}$ & $\begin{array}{l}\text { Insem. } \\
\text { index }\end{array}$ & $\begin{array}{l}\text { Average } \\
\text { age } \\
\text { months } \\
\text { days }\end{array}$ & $\begin{array}{l}\text { Mean } \\
\text { time } \\
\text { between } \\
\text { I st } \\
\text { insem. } \\
\text { and } \\
\text { concept }\end{array}$ \\
\hline
\end{tabular}

$\begin{array}{lllllllllllll}\begin{array}{l}\text { Synchro- } \\ \text { nized }\end{array} & 402 & 298 & 74.0 & 355 & 88.4 & 396 & 98.5 & 1.24 & 16.2 & 486 & 7.37 \\ \begin{array}{l}\text { Controls } \\ \text { Con }\end{array} & 202 & 109 & 54.0 & 156 & 77.2 & 190 & 94.0 & 1.63 & 17.5 & 525 & 32.20\end{array}$

It followed from the results shown that given a careful choice of animals using a single evaluation of the condition and function of the ovary, heifers can be prepared for synchronisation very responsibly, and a high degree of synchronisation of the oestral response and a good conception rate can be achieved.

Out of the total of 428 heifers synchronised in group 1,402 animals showing clinical signs of oestrus ( $94 \%$ ) were inseminated. In view of the persistence of signs of oestrus $12-20 \mathrm{~h}$ after the initial insemination, reinsemination was performed on 316 animals ( $78.6 \%$ ). A group of 86 heifers ( $21.4 \%$ ) was inseminated once only, since there were no longer signs of oestrus at the time reinsemination was performed. 
Dut of the total number of 402 inseminated animals 298 (74.12\%) conceived in the first postsynchronisation oestrus, to $88.4 \%$, and after the third insemination a total of $98.5 \%$ of animals had conceived, with an insemination index of 1.24. Heifers conceived at an average age of 486 days ( 16.2 months), with $43.7 \%$ of them below this mean age.

The period from the first postsynchronisation insemination to the total conception of the first experimental group of animals was on average 7.37 days ( $\mathrm{Tab} .1$ ), which is 24.8 days sooner than the control group of heifers inseminated under conventional conditions. The control group of animals inseminated by conventional means conceived on average 32.2 days from the start of synchronisation with $54 \%$ conception after the first insemination and an insemination index of 1.6 .

This finding is considered to be of major importance as regards the economics of the method of heifer synchronisation under study, which not only contributes to the improvement of the reproductive capacity of the animals, but also leads to a reduction in the number of feeding days up to conception, an increase in natality, and a higher milk yield compared to control animals. On the basis of these findings the heifers would, following synchronisation, enter the reproduction and production periods of their lives 24.8 days earlier, and at a daily yield of $15 \mathrm{~kg}$ would produce $372 \mathrm{~kg}$ more milk than their counterparts involved in a conventional insemination programme. In addition, 100 heifers synchronised in this way can, with $74 \%$ postsynchronisation conception, increase their natality to 6.68 calves.

The effect of breed on the conception rate is shown in Tab. 2 . Though there is a certain variation in conception between groups $(74-80 \%)$, the differences are not statistically significant.

In the case of Friesian black and white heifers ( $N$ C ) there was a conception rate of $74 \%$ after the Ist insemination on average, with a total pregnancy rate of $100 \%$ after three inseminations, and an insemination index of 1.3. animals conceived at a mean age of 15.18 months ( 455.4 days), with $66.6 \%$ of them younger and $33.3 \%$ of them older than this mean. Of the total number of conceptions the mean was 7.75 days after the first postsynchronisation insemination.

In heifers of the Bohemian Pied breed (CSTR) conception after insemination in synchronised oestrus was also high, averaging $76.8 \%$. With a total pregnancy rate of $97.4 \%$, animals on average conceived 8.58 days after the first insemination and had an insemination index of 1.17 and an average age of 17.17 months ( 515.7 days).

Crosses between the two breeds mentioned above (ČSTRXNČ) had the best pregnancy rate in synchronised oestrus, averaging $80.6 \%$. A total of $97.6 \%$ of an:mals conceived, with an insemination index of 1.09 , a mean age of 16.12 months ( 483 days) and an average time of conception of 6.51 days after the first insemination.

Crosses between Bohemian Pied cattle (ČSTRxAy) and Ayrshires had a mean pregnancy rate of $73.5 \%$ in synchronised oestrus, with a total conception rate of $100 \%$ and an insemination index of 1.23 . Animals conceived on average 5.15 days after the start of insemination, with an average age of 16.83 months ( 505 days).

The situation in the last group, which comprised a mixture of unidentified crosses, was the same. In synchronised oestrus 
Table 2

Reproduction parameters in heifers of various breeds and crosses between them after selective synchronisation with luteolytics i.m. at a dose of 500 ug (Estrumate)

\begin{tabular}{|c|c|c|c|c|c|c|c|c|c|}
\hline $\begin{array}{l}\text { Type of } \\
\text { animal }\end{array}$ & Number & $\begin{array}{l}\text { Co } \\
\text { No. } \\
\text { of } \\
\text { anim. }\end{array}$ & $\begin{array}{l}\text { n c e p t } \\
\text { In } \\
\text { synchr. } \\
\text { oestrus }\end{array}$ & $\begin{array}{l}\text { i o n } \\
\text { Ostrus } \\
\text { after } \\
\text { IInd } \\
\text { ins. }\end{array}$ & $\begin{array}{l}\text { in } \% \\
\text { Total }\end{array}$ & $\begin{array}{l}\text { Insem. } \\
\text { index }\end{array}$ & $\begin{array}{l}\text { Average } \\
\text { months }\end{array}$ & $\begin{array}{l}\text { age } \\
\text { days }\end{array}$ & $\begin{array}{l}\text { Mean time } \\
\text { between } \\
\text { i st insem } \\
\text { and con- } \\
\text { ception }\end{array}$ \\
\hline NČ & 58 & 43 & 74.13 & 90.0 & 100 & 1.3 & 15.18 & 455.4 & 7.75 \\
\hline ČSTR & 60 & 46 & 76.66 & 87.5 & 97.4 & 1.17 & 17.19 & 515.7 & 8.58 \\
\hline ČSTR $\times N$ & VČ 68 & 55 & 80.80 & 96.6 & 97.0 & 1.09 & 16.12 & 483.6 & 6.51 \\
\hline ĆSTR $\times A$ & Ay 74 & 55 & 74.32 & 100 & 100 & 1.23 & 16.83 & 487.2 & 5.15 \\
\hline $\begin{array}{l}\text { Cross } \\
\text { breed }\end{array}$ & 162 & 123 & 75.92 & 82.1 & 94.4 & 1.31 & 16.24 & 487.2 & 210.40 \\
\hline
\end{tabular}

75.6 animals conceived, with a total pregnancy of $94.7 \%$, an insemination index of 1.31 , and average pregnancy after 10.4 days following the first insemination, at a mean age of 16.24 months ( 487.2 days).

The high rate of conception and the economic impact of this method od synchronising oestrus were a stimulus to the commercial exploitation of this method, so that oestrus synchronisation has now become routine at the slusovice $A C$.

In 1982 to 1984 a total of 3406 animals of various breeds (group 2) was synchronised, mainly using Destrophan (Spofa), of which 2465 heifers conceived at the first postsynchronisation insemination, an average of $72.3 \%$ ( Tab. 3), which roughly corresponds to previous results ( $B$ a 11 et al. 1980; $H O{ }_{1} \dot{y}$ and

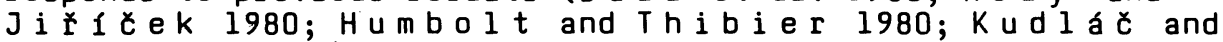
Holy 1984, etc.), and confirms the high effectiveness, rationality and professional correctness of the method described above in clinically selected heifers, since it offers clear economic advantages even under normal large-scale cattle-farming conditions. It could, of course, be argued that the selection of heifers for synchronisation on the basis of clinical examination is more laborious than the dual administration system which is suggested by manufacturers. We think, however, that the administration of luteolytics is justified only when these substances are directed towards a functional corpus luteum. Only then can this type of treatment perform its function and play an effective role in the process of controlled reproduction. Thus the success of synchronisation depends on accurate diagnosis of the corpus luteum ( $P$ l u nket $t$ et al. 1984).

In this connection it must be stated that the economic sense of the method of clinical selection of heifers for synchroni- 
Table 3

Conception of heifers in postsynchronisation oestrus with routine use in production practice (Oestrophan, Spofa)

\begin{tabular}{lccc}
\hline Year & $\begin{array}{l}\text { Total no. of inse- } \\
\text { nated animals }\end{array}$ & $\begin{array}{l}\text { No. of animals } \\
\text { conceiving in } \\
\text { postsynch. oestrus }\end{array}$ & $\begin{array}{l}\text { O\% of animals } \\
\text { conceiving }\end{array}$ \\
\hline 1982 & 1186 & 874 & 73.69 \\
1983 & 1364 & 989 & 72.50 \\
1984 & 856 & 602 & 70.32 \\
\hline Total & 3406 & 2465 & 72.37 \\
\hline
\end{tabular}

sation lies not only in the earlier entry of animals into the reproduction process, but also in the fact that the cost of luteolytics is cut considerably and a great reduction is made in the number of visits made by the inseminator, resulting in further savings.

Insemination $72 \mathrm{~h}$ after the administration of luteolytics with reinsemination 18 - $22 \mathrm{~h}$ later is justified where signs of oestrus persist. Where at the time when reinsemination would be performed all signs of oestrus have disappeared, which in our experiments was the case in $21 \%$ of animals, further insemination is not required, since the level of conception in the 86 heifers in this group inseminated once only was $76.74 \%$, i. e. $2.5 \%$ more than the mean of postsynchronisation conception following reinsemination. But this fact does nothing to alter the significance of postsynchronisation reinsemination, only underlining the necessity of the continual monitoring of oestrus, which is decisive for further fertilisation.

Some authors, such as Cobper (1975), Haf s et al. (1975), $\mathrm{Z}$ u ber (1978) and others, recommend a single insemination $80 \mathrm{~h}$ after the synchronising luteolytic stimulation, stating that the conception rate is similar to that following insemination after $70-80 \mathrm{~h}$. In our experiments the signs of oestrus were decisive for reinsemination, and where these were present reinsemination was carried out in all cases. This measure may have contributed to the high conception rate in the postsynchronisation oestrus, which is well above that reported in the literature available to us.

Another reason for the high rate of conception was undoubtedly the excellent oestrus response of animals reacting to luteolysis. This was probably due to the function of the oestrogens present in the interoestral cavitary follicles, which condition the effect of the exogenously administered luteolytic similarly as in the normal cycle. Though in this case endogenous luteolysis

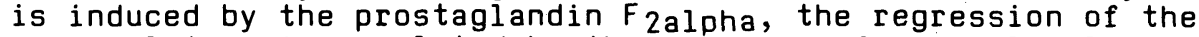
corpus luteum is regulated by the presence of ovarial follicles 
or their oestrogens. These substances affect the start of the luteolytic process by the induction of the uterine secretion of PGF2alpha (Thatcher et al. 1983), whose main precursor is arachidonic acid, which accumulates in the endometrium in high concentrations immediately before the prostaglandins appear in the uterus and the venous uterine blood ( $H$ anse 1 et al. 1975; Lamothe et.al. 1977).

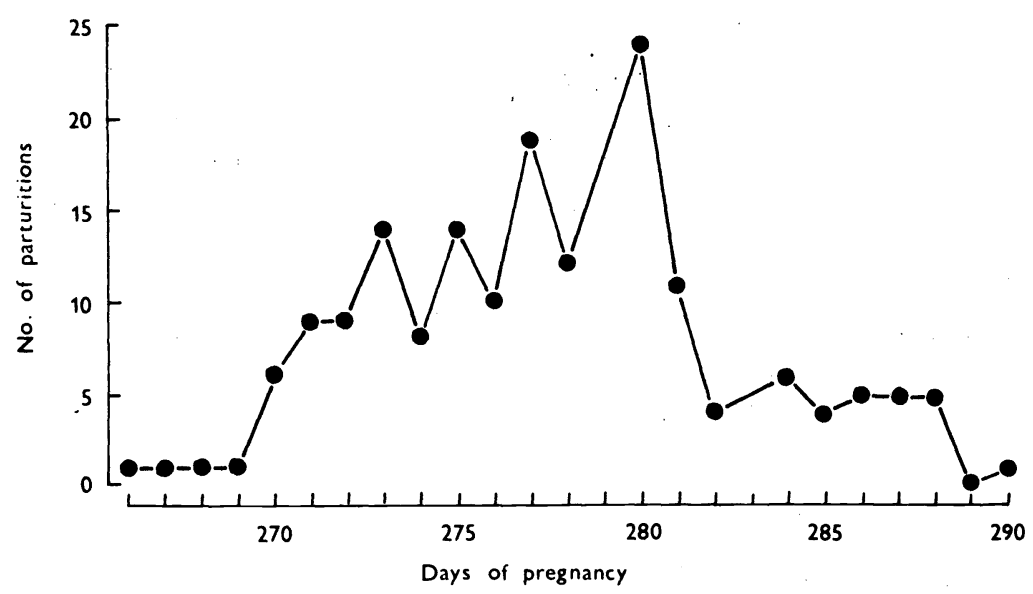

Fig. 1. Frequency of calving after oestrus synchronisation and synchronised insemination in Friesian black and whites.

The mass onset of oestrus and the high percentage of conception following a single administration of luteolytics of the control type also offer theoretical conditions for the synchronisation of calving ( $H \circ l_{y}$ and $\mathrm{Ji}$ ic ek 1980; G a r gulak 1982).

Under conventional reproduction conditions it is known that around $95 \%$ of cows and heifers maintain a gestation period of between 270 and 290 days, and the frequency of calving has a more or less regular Gaussian distribution (B a i e r 1978).

The effect of synchronised insemination on the frequency of the onset of calving was studied in detail in animals which were left in the herd (group 3), mainly heifers of the Fresian black and white breed and crosses between the latter and the Bohemian Pied.

In a group of 191 heifers of the Friesian black and white breed calving took place between 266 and 290 days after. insemination, i. e. Within an interval of 25 days ( $F i g .2$ ), with the peak of the curve around the 15 th day. The maximum number of calvings was on the 280th day of pregnancy (24, or 12.56\%), and the greatest concentration of calvings was between the $273 \mathrm{rd}$ and the 281 st days. In this nine-day period 129 heifers calved, i. e, $67.5 \%$ of the total. Prior to this main period only 28 heifers calved $(14.6 \%)$, after it 35 heifers, or $18.3 \%$. In a period of 19 days 186 heifers ( $97.32 \%$ ) therefore calved, which accords with previous experience (B a i e 1978). 


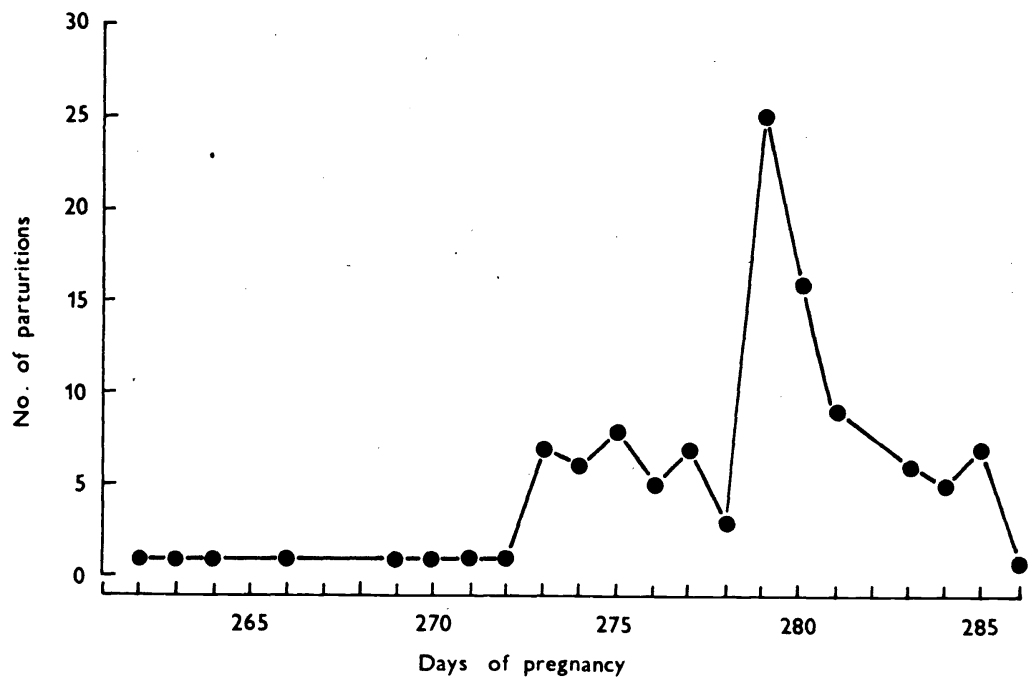

Fig. 2. Frequency of calving after oestrus synchronisation and synchronjsed insemination in cross between Czech red and whites and Friesians

The mean gestation period in black and white hejfers was 277.7 $( \pm 3.12)$ days, with male calves $(50.26 \%)$ being carried on average 0.56 days longer than females.

The crosses between the black and white Friesians and the Bohemian Pied cattle formed a group of 112 animals. In this group calving took place from the 262 nd to the 278 th day of gestation, $i$. e. over a period of 25 days, with an average duration of gestation of $278.27( \pm 3.12)$ days. Male calves were born 0.72 days later than females. The peak calving day was the 279 th, when $22.32 \%$ of heifers calved.

Among the highest concentrations of calvings were those on the 272 nd to 281 st days, with $76.78 \%$ of animals calving. Between the 279 th and the 281 st days $44.6 \%$ of heifers terminated, and within a few days the parturition curve petered out entirely.

Out of the total of 303 heifers of the Friesian breed and their crosses with Bohemian Fied which conceived after postsynchronisation insemination, the calving period took place within an interval of 29 days, i. e. from the 262 nd to the 290 th days of gestation, with the frequency maximum between the $273 \mathrm{rd}$ and the 281 st days (Fig. 3 ), when 214 animals calved in 9 days, i.e. 70.6\%. Prior to this main calving period 35 heifers calved (11.55\%) and after it 54 (17.82\%).

The duration of gestation, or the calving times, following postsynchronisation insemination varied considerably in both groups of animals, and as Ba i r (1978) found, their distribution approached a Gaussian one, spread between the 262 nd and. the 290 th days of gestation (Fig. 3). The black and white Frie sians calved within a 25-day period, similarly to the cross-bred 


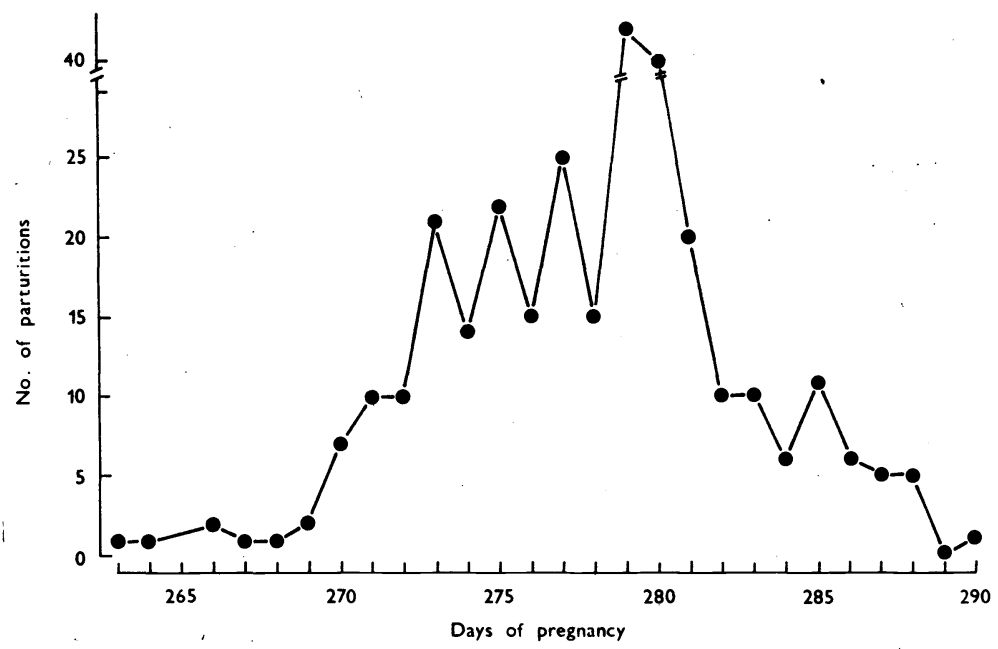

Fig. 3. Frequency of calving after oestirus synchronisation and symchronised insemination in Friesians and crosses

animals, but the Friesians went through the calving wave four days later (266th to 290 th days) than the crosses with Bohemian Pied (262nd - 286th days).

The ascertainment of the range of the onset of calving after synchronised insemination is important particularly under conditions of large concentrations of cattle, where there is an effort to synchronise the reproduction process not only at the start, i. e. at insemination, but also at the climax, i. e. at calving.

It was shown that natural synchronisation of calving in connection with postsynchronisation of insemination is not possible, since a maximum of $70 \%$ of calvings is concentrated in an approximately nine-day interval. From the point of view of ensuring continuity of calving frequency this does mean, however, that it would be possible to synchronise oestrus using luteolytics at approximately 9 to 10-day intervals, when the ends of the curve of the final phase of the last postsynchronisation calving cycle and the initial phase of the next would occur in the main period of the present one (Fig. 4).

Otherwise it would be possible to deal. with the question of concentrating calving in a shorter period by the administration of corticosteroids or luteolytics, but this has major disadvantages, particularly the high frequency of retention of the placenta and other postpuerperal complications, which have a deleterious effect not only on the animal's hepith, but also on its production and further reproduction. 


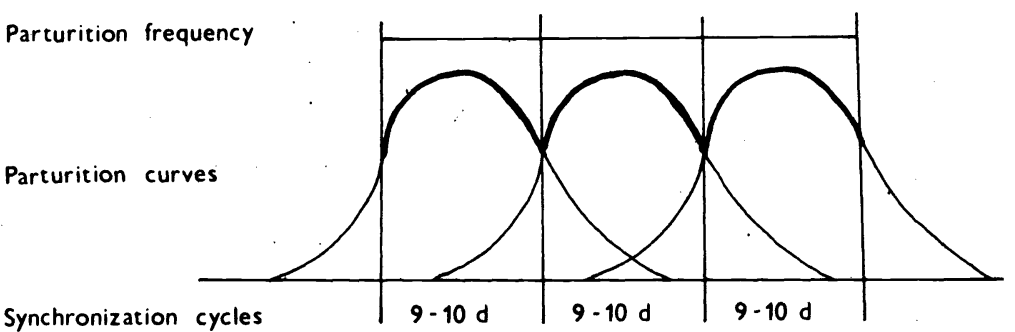

Fig. 4. Possibility of forming 9 to 10-day synchronisation "periods to ensure continuity of calving

\section{Využiti luteolytik $v$ procesu żzené reprodukce jalovic ve vztahu $k$ zabǐezávání a turnusovému nástupu porodú}

Na základě jednorázového klinického výběru zviłat k synchronizaci łije podle pł́tomnosti žlutého téliska na vaječniku byly aplikovány jednorázově luteolytické pł́pravky na bázi Cloprostenolu (Estrumate, ICI a Destrophan, Spofa) v dávce 500 mikrogramú i: m. celkem 3834 jalovicím 5 rủznou plemennou płŕslušností.

V prvni skupiné bylo synchronizováno celkẹm 428 jalovic, z nichž bylo 402 ( $94 \%$ ) inseminováno a 298, tj. 74,12 \% zviłat $v$ postsynchronizačn ŕ cich koncipovalo celkem 98,5 \% jalovic při inseminačn im indexu 1,24 .

$Z$ poctu 202 kontrolnich jalovic inseminovaných tradicnım zpùsobem zabrezlo po prvni inseminaci 54 \% a celkem koncipovalo 94,05\% zviłat płi inseminačnim indexu 1,63.

Celá pokusná skupina synchronizovaných jalovic zabřezlých

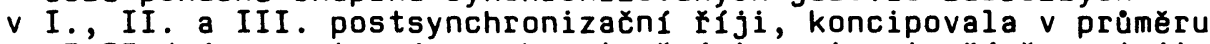
za 7,37 dní po ystupní synchronizačni inseminaci, čımž se jejich vstup do reprodukce proti klasicky inseminovaným kontrolám urychlil o 24,8 dne.

Potvrdilo se, že klinický výběr zviłat $k$ synchronizaci na základě pritomnosti žlutého tělíska na vaječniku, je vysoce efektivní a účinný a závisí na presnosti diagnostiky žlutého těliska.

Ve druhé pokusné skupinè bylo za podobných kriteríi selekce synchrónizováno 3406 jalovic, z nichž koncipovalo v postsynchronizačni íji 2465 zviłat, tj. v prủměru 72,2 \%.

Ve tretí skupinè byl sledován nástup porodú po turnusové inseminaci celkem u 303 zabrezlých jalovic nižinného a ceského strakatého skotu. Porody proběhly od 262 . do 290. dne gravidity $v$ intervalu 29 dni, płi maximálni frekvenci mezi 273 . až 281. dnem březosti, kdy se otelilo 70,62 \% zvił̌at. 


\begin{tabular}{|c|c|c|c|c|c|c|c|c|c|c|}
\hline менение & & тес & ити & : киX & пре & & & B & $\pi$ & \\
\hline репродукции & & गOX & по & От НОШ & ению & $\mathrm{x}$ & $3 a b$ & epe & менению & \\
\hline & $\mathbf{K}$ & туро & Вому & наст & уплен & ию & pod & $O B$ & & \\
\hline
\end{tabular}

На основе одноразового клинического отбора животных для синхронизации течки по присуствию желтого тела на яичнике применяли один раз лютеолитические препараты на базе клопростенола (Estrumate, $|C|$ и Oestrophan, Spofa) дозой 500 микрограммов внутримышечно у 3834 телок разного племени.

В первой группе синхронизировали 428 телок, из числа хоторых были 402 телки (948) искусственно осеменены и 298. т.е. 74,128 животных в постсинхронизационный период течки забеременели. После следующих двух искусственных осеменений забеременело 98,58 телек при индексе осеменения 1,24 .

Из 202 хонтрольных телох, осемененных традиционным способом, после первого осеменения забеременели 548 , в итоге забеременели 94,058 животных при индексе осеменения 1,63 .

Вся подопытная группа синхронизированных телек, забеременевтих на 1, II и III этапе постсинхронизационных течек, в среднем забеременела через 7,37 суток после вступительного синхронизационного осеменения, в результате чего по сравнению с классически осемененными группами наступление репродукции ускорилось на 24,8 суток.

Было установлено, что клинический отбор животных для синхронизации на основе присуствия желтого тела на яичнике является высокоэффективным и зависит от точности диагностики желтого тела.

Во второй подопытной группе при наличии аналогичных критериев отбора проводили синхронизацию 3406 телок, из них в период постсинхронизационной течки забеременело 2465 телок в среднем 72,28 .

В третьей группе исследовали наступление родов после турового осеменения у 303 забеременевщих телок низменного чешского пестрого племени. Отелы протекали с 262 по 290 суток беременности в интервале 29 сутох с махсимальной частотой между 273 - 281 сутки беременности, когда телилоць 70,628 животных.

\section{Re ferences}

BAIER, W.: In Richter-Götze Tiergeburtshilfe, 3. Aufgabe, Paul Parey, Berlin-Hamburg, 1978: 118.

BALL, P. J. H. - BULMAN, D. C. - LAMMING, G. E.: Milk progesteron profiles in the diagnosis of non-detected oestrus in dairy cows and its treatment with Cloprostenol (Estrumate). In: 9th Int. Congr. Anim. Reprod. A.I. Vol. IV, 70, 1980.

COOPER, M. J.: Control of nestrous cycles of heifers with a synthetic prostaglandin analogue. Vet. Rec., 95, 1975: 200.

FULKA, J. - MOTLIK, J. - PAVLOK, A.: Metody stanovení pohlavniho cyklu hospodářských zviřat. In: Sbor. Ref. Brno vúvel, 1976 .

GARGULȦK, V.: Frekvence porodủ u turnusově synchronizovaných jalovic černostrakatého nižinného skotu. Stud. věd. práce, Brno VSV, 1982 .

HAFS, H. D. - LOUIS, T. M. - NODEN, P. A. - OXENDER, W. D.: Control of the oestrous cycle with prostaglandin $F_{2}$ alfa in cattle and horses. J. Anim. Sci. Suppl., I., 38, 1974: 10. 
HAFS, H. D. - MANNS, J. G. - DREW, B.: Onset of estrus and fertility of Zuber heifers and suckled beef cows treated with Prostaglandin $F_{2}$ alfa. Anim. Prod., 21, 1975: 13.

HAFS, H. D. - MANNS, J. G. - DREW, B.: Onset of estrus after prostaglandin F2 alfa in cattle. Vet. Rec., 96, 1975: 134.

HANSEL, W. - SHEMESH, M. - HIXON, J. - LUKAZSEWSKA, J.: Extraction, isolation and identification of a luteolytic substance from bovine endometrium. Biol. Reprod., 13, 1975: 30 - 37 .

HOL $\dot{Y}, L$. - JIŔČ́EK, A.: Využití luteolytických faktorú ve vztahu k turnusovému nástupu ríje a plodnosti. Náš chov, 40, 1980: 64. HUMBOLT, P. - THIBIER, M.: Use of progesterone measurement for the control of reproduction in cattle. In: 9 th Int. Congr. Anim. Reprod. A. I. Vol IV, 1980: 86.

JIRAN, E. - POLAK, L. - ROŽIĆKA, V.: Využití analogu PGF alfa (Destrophan Spofa) ve veterinární praxi v ČSSR. Sb.Fafmakologie reprod. hosp. zvírat, Znojmo, VúBVL, 1983.

KUDLǍC, E. - ELEČKO, J. ạ kol.: Veterinární porodnictví. Praha, SZN, 1977: 673-674.

KUDLÁ̉, E. - VRTĚL, M. - VINKLER, A.: Metody stanovení pohlavního cyklu hospodářských zviřat. In: Sbor. ref. Brno, VúVel, 1976.

KUDLAĆ, E. - HOLÝ, L.: Ŕízení a kontrola reprodukce ve velkochovech skotu. Praha, SZN, 1984: 257.

LAMOTHE, P. - BOUSQUET, D. - GUAY, P.: Cyclic variation of $F$ prostaglandins in the uterine fluid of the cow. J. Reprod. Fertil., 50, 1977: 381 .

LAUDERDALE, J. W.: Effects of PGF alfa on pregnancy and estrous cycle of cattle. J. Anim. Sci., 235 , 1972: 246.

LAUDERDALE, J. W.: Distribution and biological effect of prostaglandins. J. Anim. Sci. Suppl. I., 38, 1974: 22 .

LOUIS, T. M. - HAFS, H. D. - STELLFLUG, J. N.: Control of ovulation, fertility and endocrine response after prostaglandin $F_{2}$ alfa in cattle. Ann. Biol. Anim. Biochem. Biofys., 15, 1975: 407.

PLUNKETT, S. S. - STEVENSON, J. S. - CALL, E. P.: Prostaglandin F, alfa for lactating dairy cows with a palpable corpus luteum but unobserved estrus. J. Dairy Sci., 67, 1984: 380 .

PETIT, M. - DELETANG, F.: Control of estrus in dairy cows with prostaglandin, progesterone or combination of the both. In: 9th Int. Congr. Anim. Reprod. A.I., Vol. IV, 1980: 86.

REICHEL, F. - SEVČ́tKOVÁ, E.: Uplatnění pŕipravku Oestrophan inj. Spofa (Cloprostenol) v procesu reprodukce u hospodářských zvírat v ČSSR. Biol. Chem. Vet. Praha, 22, 1984: 253.

ROB, 0.: Systém poloŕizené reprodukce $v$ chovech skotu se sníženou plodností. Veterináství, 23, 1983: 156.

ROWSON, L. E. A. - TERVIT, R. - BRAND, A.: The use of prostaglandins for synchronization of estrus in cattle. J. Reprod. Fertil., 29, 1972: 145 .

SCHULTZ, R. H.: Synchronization of estrus in the bovine. Soc. for Theriogenology. Proc. Ann. Meeting, Kentucky, 1976.

SCHULTZ, R. H.: In Prostaglandins in Animal Reproduction II.

Proc. from a symposium held at the Swedisch Univ. of Agric. Sci. Uppsala, 3l.V. - 2.VI.1983. 
SEVČIK, B. - REICHEL, F.: Výzkum, vývoj a výroba płripravkú pri ovlivñováni reprodukce hospodárských zviłat. Sb. referátú o reprod. hosp. zviłat, VŠV Brno, 1983.

THATCHER, W. W. - CHENAULT, J. R.: Reproductive physiological response of cattle to exogenous prostaglandin $\mathrm{F}_{2}$ alfa. J. Dairy Sci., 59, 1976: 1366 .

THATCHER, W. W. - KNICKERBOCKER, J. J. - BARTOL, F. F - BAZER, F. W. - ROBERTS, R. M. - DROST, M. : Maternal recognition of pregnancy in relation to the survival of transferred embryos: Endocrine aspects. Theriogenology, 23, 1985: 129.

WELCH, J. A. - HACKETT, A. J. - CUNNINGHAM, C. J. - HEISHMAN, J. O. - FORD, S. P. - NADARAJA, R - HANSEL, W. - INSKEEP, S. K.: Control of estrus in lactating beef cows with prostaglandin $F_{2}$ alfa and estradiol benzoate. J. Anim. Sci., 4l, 1975: 1686 . 